\title{
Towards Abolition: Undoing the Colonized Curriculum
}

\author{
Angela M. Leslie ${ }^{* 1}$, Vajra M. Watson ${ }^{1}$, Rose M. Borunda ${ }^{1}$, Kate E. M. Bosworth ${ }^{1}$, \\ and Tatianna J. Grant ${ }^{1}$
}

* Corresponding author

E-mail: angela.leslie@csus.edu

1. College of Education, California State University, Sacramento, USA.

\section{Article Info}

Received: February 2, 2021

Revised: April 14, 2021

Accepted: May 24, 2021

\section{$10.46303 / j c s r .2021 .5$}

\section{How to cite}

Leslie, A.M., Watson, V.M., Borunda, R.M., Bosworth, K.E.M.

and Grant, T.J. (2021). Towards Abolition: Undoing the Colonized Curriculum. Journal of Curriculum Studies Research, 3(1), 1-20. https://doi.org/10.46303/icsr.2021.5

\section{Copyright license}

This is an Open Access article distributed under the terms of the Creative Commons Attribution 4.0 International license (CC BY 4.0).

\begin{abstract}
Racial injustice has traditionally been observed from the viewpoint of its impact and outcomes. Subsequently, educators and policy makers have generally focused on outcomes; unequal opportunity structures, disparities in educational achievement, the school-to-prison pipeline, disproportional health indicators, incarceration rates, and harsher punishment in school and judicial systems, are just a few of the contexts by which this nation's racialized roots can be measured for present day mistreatment and disparate outcomes for minoritized populations. As policy makers and educators look to the impact of racial injustice, a true ontological vantage would reveal the cause as well as the perpetuation of these outcomes. As the current COVID-19 pandemic continues, and with increased interest in online learning, it is vital that teachers and professors seek new pedagogy and tools to teach about racism. Our study examined whether a virtual 1-hour presentation on white humanists influences students' understanding of racial justice. Our research demonstrates that a colonized curriculum impacts student's outlook on the world and themselves. Inversely, when we expose students to humanists throughout history, we are able to show that white people have a legacy and responsibility to fight for racial justice. This provides students with alternative models beyond those that perpetuate white supremacy.

\section{KEYWORDS}

Abolitionists; curriculum; whiteness; racial justice; online learning; responsive pedagogy. 


\section{INTRODUCTION}

On May 25, 2020, the world witnessed the brutal suffocation and murder of George Floyd, a Black man, at the hands of Minneapolis police officers. The officer primarily responsible for Mr. Floyd's death, Derek Chauvin is white. And the other officers that ignored Mr. Floyd's pleas are also culpable. In many ways, we're all implicated. While these public lynchings are not a new reality, the prevalence of cell phones has changed our collective consciousness because we, too, see and witness the brutality. In this era of technology, it is hard to claim ignorance to these crimes and turn a blind eye to the atrocities. The racism is in full view.

Awareness and outrage to the murder of Mr. Floyd incited a worldwide response. In the aftermath of Floyd's widely broadcast murder, protestors demanded justice. Colonial monuments were toppled throughout the United States and abroad. In England, a $17^{\text {th }}$ century slave trader was dumped into Bristol Harbor. In Antwerp, a Belgian king who brutalized the Congolese was burned and removed. In the wake of social unrest, dozens of statues symbolizing colonizers who oppressed BIPOC (Black, Indigenous, People of Color) tumbled to the ground. During this same historic moment, another act went viral and took hold of our psyche. On January 6, 2021, white supremacists stormed the U.S. Capitol. There was shock and disbelief heard around the nation; how could this form of domestic terrorism exist on this soil, in this land?

Technology has opened our eyes to that which we can no longer ignore. On that particular winter day in January, we witnessed a visceral and violent eruption of whiteness, ${ }^{1}$ whose roots run deep throughout our daily lives. In full view, these events represent the malignant fruits of a particular tree known as white supremacy that has been seeded, watered, and flourished across many generations. Of all areas of society, schools are especially culpable in the regeneration of racism. Consider that in 1933, educational theorist, Carter G. Woodson explained that "there would be no lynching if it did not start in the schoolroom" (p. 3). As a seminal educational scholar, Woodson focuses our attention to schooling as an institution that cultivates white supremacy.

Building on this idea, this study focuses on curriculum. Who is taught about and how they are presented in classrooms is not neutral - in fact, it is ideological. Curriculum is not objective as it reproduces the hierarchal and social position that maintains white privilege (Yosso, 2002). As the current COVID-19 pandemic continues and with renewed interest in online learning, it is vital that educators seek transformative pedagogy and tools that addresses racism. Compounding the challenges of teaching online, college faculty are also examining out how to successfully adjust social justice curriculum to fit virtual spaces (Guthrie \& McCracken, 2010; Hutchison \& White, 2020). Furthermore, our research will contribute to the emerging research

\footnotetext{
${ }^{1}$ While the terms Black, Brown, and Indigenous as racial and/or ethnic identities are capitalized throughout this article, we have chosen not to capitalize the terms white or whiteness in order to highlight the sociopolitical environment in which European American dominance is erected and normalized (adapted from Lee, A.Y., \& Lee, A.J. (2020). Critical race methodologies. In Duke, N. K. \& Mallette, M. H. (Eds.), Literacy Research Methodologies (3rd ed.). The Guilford Press).
} 
on online curriculum that addresses history and social justice issues (McBean \& Feinberg, 2020). To this end, our study examined whether a virtual 1-hour presentation on white abolitionists/humanists can impact students' understanding of racial justice, collective belonging, and connection to co-conspirators (Love, 2019).

Our research reveals that a colonized curriculum impacts students' outlook on the world and how they perceive themselves in relation to others in this world. Inversely, students who are exposed to white humanists from United States history, learn that white people, in our historical record, have challenged white supremacy and have a legacy in fighting, in collaboration with People of Color, for racial justice. This legacy provides white students with role models - beyond those that perpetuate white supremacy.

Before launching into the study, we will describe the conditions that have fostered the violence and fueled the ongoing animosity and oppression directed at BIPOC. While COVID-19 has compelled us to teach via online learning, which has, in turn, fomented educational disparities, we can also recognize our growing awareness as an opportunity to reset not only who is addressed in our curriculum but how they are represented (Ladson-Billings, 2021). The merits of a balanced and truthful curriculum that cultivates desirable qualities in youth is thereby offered through modeling of individuals who, in U.S. history, have demonstrated, by word and by action, their own psycho-social integration. Awakened to the full complexities of white supremacy in education, we will establish the grounds by which to nurture a new direction for the psycho-social integration of white Euro-Americans living in this diverse nation.

\section{A Nation Seeded by Traumatized People}

The people who came from Europe in various migration waves were fleeing wars, famine, plagues, extreme punishment for minor crimes, religious persecution, and tyranny (Kelly, 2005). Exposure to actual or threatened death, serious injury, or sexual violence is considered trauma by the Diagnostic and Statistical Manual of Mental Disorders (DSM-V). The extreme conditions in Europe from the 1600s to the 1900s outweighed the unknown awaiting them in America, which compelled people to leave their homeland. The contemporary understanding of unresolved trauma indicates that "Long after a traumatic experience is over, it may be reactivated at the slightest hint of danger and mobilize disturbed brain circuits and secrete massive amounts of stress (van der Kolk, 2014, p.2). The violence and inhumane treatment experienced or witnessed, first hand by people, fleeing the European nations resulted in a traumatized population of exiles who upon arrival on this continent's eastern shores perceived their new reality through a lens that conveys the world as inherently unsafe. Transmitted from one generation to the next, many descendants of the various waves of refugees continue to see the world through a perceptive orientation that sustains a fight or flight orientation. This positionality projects anything deemed different as a threat, which undermines psycho-social integration. In other words, unresolved trauma turns into what is known as generational trauma, which is defined by Doucet and Rovers (2010) as "a secondary form of trauma that 
results from the transfer of traumatic experiences from parents to their children" (p. 94). To this point, Menakem (2017) states that "trauma ... was passed from one European body to another during the Middle Ages" through generations onto their descendants who sought refuge on this continent then instilled in the bodies of many Africans, Native people, the very soil, and the earth (p. xv).

The manifestation of this generational trauma is encapsulated in the Cree term, Wétiko, whose literal translation is "cannibalism" and whose presence has adversely impacted the Americas for over 500 years. More specifically, Wétiko is defined as a "cult of aggression and violence." An expanded definition of Wétiko means "consuming of other creatures' lives and possessions ... a psychosis, the greatest epidemic sickness known to man" (Forbes, 2008, p. xvi). This toxic condition has led to the annihilation on this continent's natural resources, plant life, and various animal species while unleashing the genocidal attack and systematic oppression of BIPOC. Further application of this term speaks to the pervasive nature of this psychological condition:

The rape of a woman, the rape of a land, and the rape of a people, they are all the same. And they are the same as the rape of the earth, the rape of the rivers, the rape of the forest, the rape of the air, the rape of the animals. Brutality knows no boundaries. Greed knows no limits. Perversion knows no borders. Arrogance knows no frontiers. Deceit knows no edges. These characteristics all tend to push towards an extreme, always moving forward once the initial infection sets in. (Forbes, 2008, xvi)

Violence of the magnitude exacted upon and brought into the Americas can be explained by two concurrent phenomena. The first involves the impact of unresolved trauma. Van der Kolk (2014) explains how this condition negatively colors the way the world and all in it are viewed:

Trauma can turn the whole world into a gathering of aliens. ... Isolating oneself into a narrowly defined victim group promotes a view of others as irrelevant at best and dangerous at worst, which eventually only leads to further alienation. Gangs, extremist political parties, and religious cults may provide solace, but they rarely foster the mental flexibility needed to be fully open to what life has to offer and as such cannot liberate their members from their traumas. Well-functioning people are able to accept individual differences and acknowledge the humanity of others. (p. 77)

In the mind and hearts of those who have inherited a trauma-framed worldview, the tendency to adopt marginalizing attitudes of others is easily captivated by fear mongering and demonizing of people who are cast as "different." White supremacist thinking draws from the reptilian brain, which is activated in response to novel or changing circumstances such as changing demographics. Conspiracy addiction, a weapon employed by extreme white supremacist ideology, appeals to the fight/flight response as seen in the attack on the nation's Capital on January 6, 2021. Fueled by rhetoric that triggers the primitive brain, rather than the prefrontal cortex's cognition and higher-level thinking, the embodied trauma brought to these shores from Europe continues to explode. 
The second phenomena to consider in understanding the full nature of White Supremacy can be framed by dislocation theory. This theoretical framework indicates that:

Psychosocial integration is experienced as a sense of identity, because stable social relationships provide people with a set of duties and privileges that define who they are in their own minds. Lack or loss of psychosocial integration fosters alienation or disconnection ... or "poverty of the spirit." (Alexander, 2010, p. 59-60)

In evolving past the primitive brain, steps forward must include ways to heal the trauma, instill a positive identity, and promote positive psychosocial integration. In providing examples of historical humanists who model positive identity and who have bridged the polarizing forces of race, we look to how we can address this evolvement through the curriculum offered in our classrooms.

\section{LITERATURE REVIEW}

Online curriculum that addresses contentious topics such as racism and white privilege can also benefit from culturally responsive pedagogy. Gay (2018) describes culturally responsive teaching as instruction that is centered "in multiethnic cultural frames of reference" (p. xxvii). The intent of the pedagogy is to facilitate the social capital of all students in the classroom (Woodley, Hernandez, Parra, \& Negash, 2017). To accomplish this, the curriculum and teaching should embody the following principles of validating all students' experiences and strengths, create a sense of shared community within the classroom and through empowering curriculum (Gay, 2018). Curriculum should validate all students' identities and foster a space for them to be seen in curricular materials. Teachers who implement culturally responsive education value students' cultural backgrounds and use social capital as a bridge to foster better relationships and learning (Woodley, Hernandez, Parra, \& Nash, 2017). Community building then leads to a safe place to engage students to challenge stereotypes, critique social institutions, and question the truth in history (Gay, 2018). The importance of reimagining curriculum lies in the fact that much of historical curriculum continues to be framed from the master narrative (Brown \& Au, 2014). These obstacles are further complicated by the challenges of online teaching.

There is considerably less research on how to accomplish anti-racist education virtually. Several researchers have incorporated social justice pedagogy in the application of learning and curriculum in online courses (Guthrie \& McCracken, 2010; Hutchison \& White, 2020). Hutchison and White (2020) examined the successful integration of culturally responsive and social justice pedagogy in an online Doctor of Education program. Their intent of combining pedagogical concepts simultaneously stresses the importance of empowering BIPOC students' voices and experiences through culturally responsive teaching, while calling attention to the systemic issues surrounding a particular group of people with the goal of effecting change and action. There has been considerably more research on how to incorporate culturally responsive pedagogy in the K-12 classroom rather than in higher education courses (Ginsburg \& Wlodkowski, 2009). More recent emerging work has focused on providing best practices for 
fostering culturally responsive pedagogy in the online college classroom (Morong \& DesBiens, 2016; Rhodes \& Schmidt, 2018; Woodley et al., 2017). Faculty success in transferring complex topics such as racism to virtual education is key to furthering students' understanding of systemic issues.

The parallels between culturally responsive pedagogy and critical race theory (CRT) lies in the foundation that racism is embedded in institutional structures, including the educational system (Delgado Bernal, 2002; Ladson-Billings, 2021; Solórzano \& Delgado Bernal, 2001) and in curriculum (Brown \& Au, 2014; McBean \& Feinberg, 2020; Yosso, 2002). Critical race scholars have called attention not only to the underrepresentation of historical content in curriculum but also to how whiteness is centered to maintain hierarchal power (Brown \& Au, 2014; McBean \& Feinberg, 2020; Yosso, 2002). Yosso (2002) developed key critical race curriculum strategies that stem from the tenets of CRT that include "the potential to (1) challenge racism, sexism, classism, and other forms of subordination; (2) provide students with an oppositional language to challenge deficit social discourses; (3) empower teachers, students, and parents as they focus on the strengths within communities of color to combat racism, sexism, classism, nativism, monolingualism, and homophobia in education; (4) facilitate movement towards critical consciousness inside and outside classrooms; (5) utilize the strengths of various critical frameworks to work towards social justice" (p. 102). Both critical race curriculum and culturally relevant pedagogy exposes the inequalities in traditional curriculum by reconceptualizing historical knowledge and how history is taught.

Part of our humanist curriculum does center on whiteness, yet the content is focused on how white abolitionists offered their power and privilege for the greater good of African Americans and Native Americans in their fight to overturn the atrocities of enslavement, displacement, and genocide. Teaching about racism may seem daunting to instructors teaching online, nevertheless there is hope that further studies in this area will provide future curricular strategies. One earlier study provided some optimism regarding the positive aspects of teaching about sensitive topics online. Merryfield (2003), who has several decades of online teaching experience at the collegiate level, offers extensive and valuable lessons on using cross-cultural skills to develop curriculum that benefits all learners. Interestingly, Merryfield has discovered advantages of having online discussions on controversial topics. In particular, the researcher found virtual learning acted "as a veil to protect people as they reveal, question, and take risks" (p. 154). Part of the risk taking that comes with online anonymity has the potential to push students out of their comfort zone, which can be harder to accomplish with the occasional awkwardness or tensions when having difficult face-to-face conversations. By uncovering the hidden curriculum of white abolitionists, our work is positioned to dismantle students' understanding of white supremacy and offer the necessary tools to expand the conversation of racist issues today.

The benefits of a semester long class devoted to unpacking humanists in history have been well documented (Borunda, 2012; Borunda, 2020; Leslie \& Borunda, 2019). More recently, 
a study confirmed that humanist curriculum condensed into a 1-hour workshop could be effective in dismantling preconceived ideas about historical and contemporary cross-racial relationships (Leslie \& Borunda, 2021). Both studies confirmed that students' self-perceptions of their racial identity and hope for positive cross-cultural connections were improved by learning about humanist role models. More importantly, students also recognized that advocacy and working together across racial lines was key to dismantling racism. Our work intends to add to the growing literature on how to effectively incorporate antiracist curriculum in an online setting.

\section{METHODOLOGY}

The purpose of the research described in this article is to examine whether the effectiveness of an abolitionist integrated curriculum could be transferred to online teaching. A mixed methods approach was utilized for the collection of both quantitative and qualitative data. Creswell and Plano Clark (2007) point out that utilizing both methods contribute to a richer understanding because layering data strengthens the findings. For this study, data was collected through an anonymous online survey built in Qualtrics (www.qualtrics.com). The survey included questions that solicited both closed and open-ended responses.

Data was collected by two graduate student research assistants, Kate Bosworth and Tatianna Grant, who presented 1-hour workshops in nine undergraduate and graduate level classes that covered information on white abolitionists in history who fought for racial justice. Whereas data for previous iterations of this research was gathered via in-person workshops and held during in-person classes, this study conducted workshops online with the use of Zoom in classes that were held online due to the COVID-19 pandemic. Participants consisted of 122 undergraduate and post baccalaureate students from classes in the College of Education at a Northern California university. These classes were selected based on their relation to themes connected to the content of this study. The workshops were conducted during regularly scheduled class time. Students accessed the Qualtrics survey on their home computer, laptop, or cell phone during the Zoom workshop, ensuring that their responses were anonymous. To understand the impact of the curriculum, we sought to answer four main research questions:

1. Does material that presents a humanist-focused counter narrative positively shift students' self-identity development?

2. Does the knowledge of historical humanistic figures positively shift students' perceptions of other people?

3. Does humanist curriculum change how students see issues of race and racism today?

4. Does the workshop promote future changes for students in how they approach their careers or social development? 


\section{Curriculum Process and Data Collection}

\section{Survey Part 1}

First, students were given instructions and a link to Part 1 of the online survey, which displayed photographs of 12 individuals without any identifiable names or information, one at a time, and gave students 5 minutes to type the name of each individual. Students were told that if they did not know the name of an individual they could leave items blank or make guesses. Photographs \#1-6 depicted the images of Andrew Jackson, Colonel George Armstrong Custer, Christopher Columbus, George Washington, Thomas Jefferson, and Benjamin Franklin. These are common historical figures represented in our K-12 curriculum. Photographs \#7-12 depicted humanists, John Brown, William Lloyd Garrison, Angelina Grimké, Sarah Shaw, Colonel Robert Shaw, and Helen Hunt Jackson. The first five individuals are known for their work in abolitionism and the last is known for her work in supporting Native American causes during the 1800's. The work of these individuals is documented in national archives and publications but seldom, if at all, addressed in our K-12 curriculum. Nonetheless, their work provides testament to ideologies that were in direct contrast to the first six aforementioned figures.

\section{Survey Part 2}

After students completed Part 1 of the survey, the research assistants provided the names of the 12 individuals and asked students to record the number of photographs \#1-6 they correctly identified, and the number of photographs \#7-12 correctly identified. Students were then given a link to Part 2 of the online survey, which displayed the photographs of the same 12 individuals, this time including each individuals' name. Students were given 6 minutes to type what they knew about the individuals. Again, students were told that they could leave items blank or make guesses.

\section{Presentation and Survey Part 3}

After students completed Part 2 of the survey, the research assistants gave a 15-20 minute presentation describing each of the 12 individuals and their historical significance. Students were then given a link to Part 3 of the online survey, which asked them to report the number of individuals they correctly identified in Part 1 of the survey, report the number of individuals they accurately described after the names were revealed in Part 2 of the survey, and to respond to the following questions:

1. Were there disparities between what you knew about the first six individuals presented (\#1-6) versus the second six individuals presented (\#7-12)? If so, how do you account for the disparity?

2. Were there differences in the world views, values, and accomplishments of the first six individuals presented (\#1-6) versus the second six individuals presented (\#7-12)? If so, what is the significance in the differences and the weight of their promotion in our rendering of history?

3. What thoughts/feelings do you have, if any, after hearing about humanist EuroAmericans? 
4. Knowing what you know now about humanists in history, will this change anything for you socially or in relation to your future career?

Students were given 10 minutes to complete Part 3 of the survey and were thanked for their participation. The research assistants were then available to answer questions from students.

Our research questions were motivated and informed by culturally responsive teaching (Gay, 2018). Gay highlights eight categories that reference how teachers can employ these tenets in curriculum and classroom instruction. Our curriculum design attempted to integrate many of these principles in the workshop. Gay addresses validation as a way to encourage students to "know and praise their own and one another's cultural heritage" (p. 37). The presentation used in the workshops was based on Borunda's (2012) curriculum on humanists in history and is grounded in the counter narratives and empowering stories of people of color and white abolitionists who collectively worked together to eradicate systems of white supremacy. One of the elements of comprehensive and inclusive curriculum targets BIPOC students as well as white students in mutually beneficial ways. Our curriculum highlights how history is taught from a limited Eurocentric perspective and offers students a new way of looking at how the past bears upon present day circumstances, which includes the current racial divide.

Armed with the newfound knowledge of historical cross-racial relationships, our hope is that students will become empowered by the legacies of liberation in this country. Part of the wider view of empowerment lies within students in their identity development and figuring out who they are as human beings (Gay, 2018). Our open-ended reflective questions were intended to guide students to look within and reflect on what they could gain personally or professionally from the information given in the presentation. Part of our curriculum design garnered from white students a different emotional response to the topic of white power and privilege. So often students get caught up in being defensive and guilty when confronted with discussions on race (DeAngelo, 2018). Gay (2018) centers teaching as transformative in how instructors shape their curriculum:

One direction deals with confronting and transcending the cultural hegemony nested in much of the curriculum content and classroom instruction of traditional education. The other develops social consciousness, intellectual critique, and political and personal efficiency in students so that they can combat prejudices, racism, and other forms of oppression and exploitation. (p. 420)

Our study attempted to employ the duality of a double consciousness (DuBois, 1903) within the presentation by engaging and asking students questions throughout the workshop and giving the students opportunities for self-reflection through the open-ended survey questions.

Part of emancipatory curriculum teaches students to recognize that history and curricular material can stem from a false narrative. Gay (2018) shares that "culturally responsive pedagogy lifts the veil of presumed authority from conceptions of scholarly truth typically 
taught in schools" (p. 43). The curriculum in this study serves as a call to action for students to question what they have been taught in history and who is represented in curriculum by specifically asking them to reflect on the disparities of their past knowledge of humanists. Teaching students that traditional history curriculum is derived from a capitalistic and exploitive Eurocentric perspective, particularly featuring slave owners as "heroes," demonstrates how this historical view is seen as normative and ethical. Gay emphasizes the need for curriculum and teaching to be humanistic in that students are guided by humanity and through the interconnectedness of all people. Gay further recommends that students who are open and respectful of one another can ultimately relate and empathize with others and that this can lead to a caring and supportive society.

\section{Data Analysis}

Data from the three parts of the survey were exported from Qualtrics in spreadsheets with no personally identifying information, ensuring the anonymity of participants. The data from Part 1 of the survey was tabulated to quantify the number and percentage of participants who correctly identified each of the 12 individuals. The Part 2 data was tabulated to show the number and percentage of participants who provided any correct information describing each of the 12 individuals. The percentage of participants who correctly identified or had knowledge of the achievements of individuals \#1-6 were compared to the percentage of participants who correctly identified or had knowledge of the achievements of individuals \#7-12.

Triangulation was used for the data analysis from Part 3 of the survey. Triangulation is the process of multiple investigators conducting data analysis to ensure the validity of the compiled results (Creswell, 2005). Data was coded and analyzed separately by the principal investigator, co-principal investigator, and the two research assistants and findings were then compared to ensure the accuracy and relevancy of the findings. The researchers completed thematic coding to interpret and make meaning of common themes emanating from responses (Creswell, 2005). Finally, descriptive statistics were used to measure who and what students knew about specific historical figures and history (Creswell, 2005).

\section{FINDINGS}

\section{Part 1: Percentage of Respondents Who Identified Each Historical Figure's Photograph}

George Washington was recognized by the largest percentage of students (87\%), followed by Benjamin Franklin (52\%). Christopher Columbus, Thomas Jefferson, and Andrew Jackson were each recognized by $25 \%-35 \%$ of students. Colonel George Armstrong Custer was recognized by only $3 \%$ of students. None of the humanist historical figures \#7-12 were recognized by more than 3\% of students, with William Lloyd Garrison and Colonel Robert Shaw at 3\%, John Brown and Angelina Grimké at 2\%, Sarah Blake Shaw and Helen Hunt Jack-son at 1\%. Part of the goal of this exercise was to glean students' knowledge of who they could recall from history to 
demonstrate what Gay (2018) calls the normative and ethical rendering of a one-sided history of Euro-Americans.

Table 1: Ability to Identify Historical Figures by Photograph

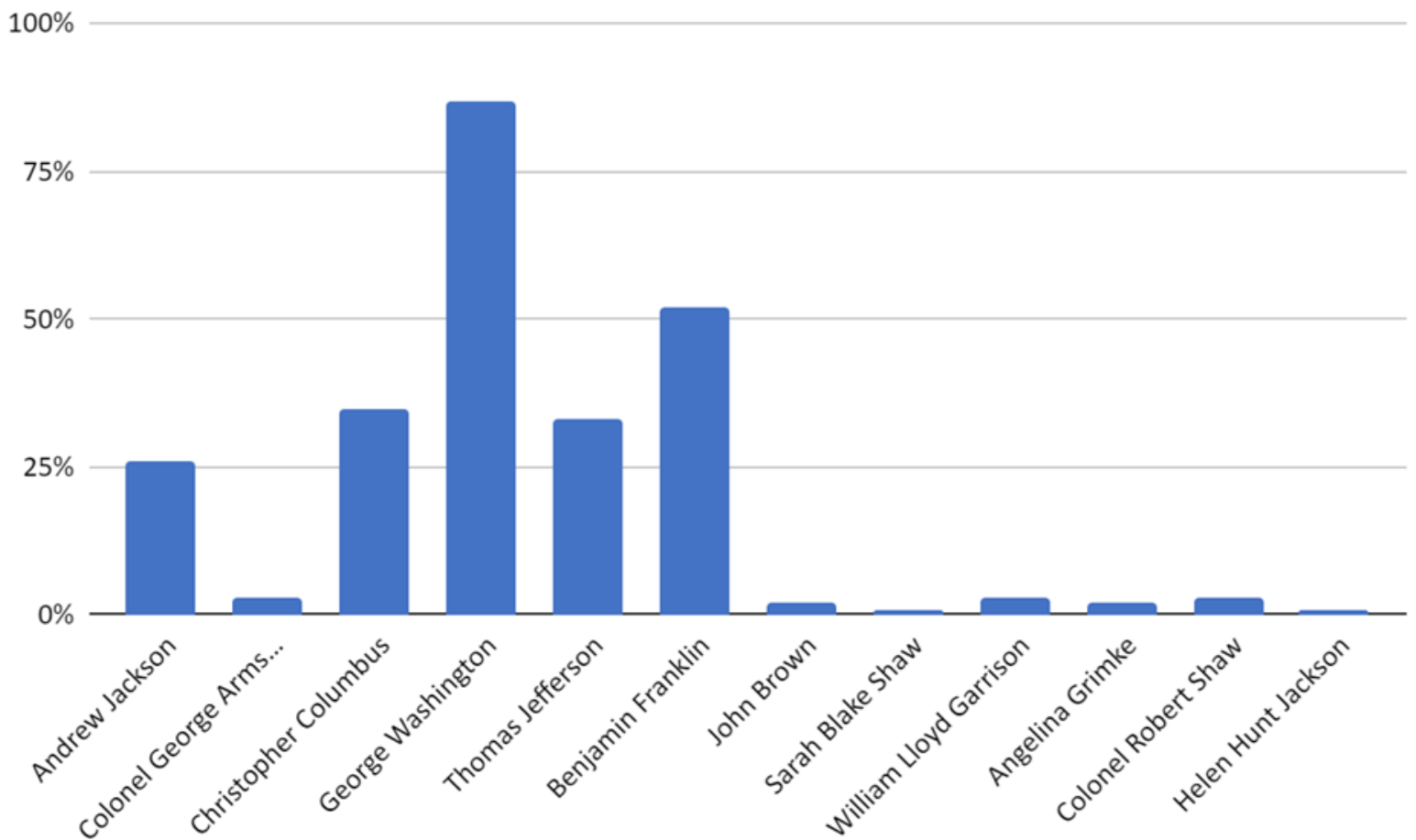

Part 2: Percentage of Respondents Who Knew Information About Each Historical Figure

Students were then asked what they knew about the individuals in history once their identities were revealed. George Washington was known by nearly all students (96\%), followed by Christopher Columbus, Benjamin Franklin, Thomas Jefferson, and Andrew Jackson who were each known by approximately $70 \%-90 \%$ of students. Colonel George Armstrong Custer was known by $20 \%$ of students. None of the humanist historical figures \#7-12 were known by more than $14 \%$ of students, with Colonel Robert Shaw at 14\%, Sarah Blake Shaw and Angelina Grimké at 9\%, John Brown and William Lloyd Garrison at 7\%, and Helen Hunt Jackson at 6\%. After students answered these questions, the presenters provided comprehensive information about the individuals and stories of cross-racial alliances in the mid-1800s. The counter narratives of people working together at one of the most difficult times in history attempted to empower BIPOC and white students and contribute to inclusive curriculum. The emphasis of this part of the workshop was engaging students to think about the humanist perspective and the interdependence of different groups of people fighting to erode white supremacy. 
Table 2: Knowledge of Historical Figures After Identification was Provided

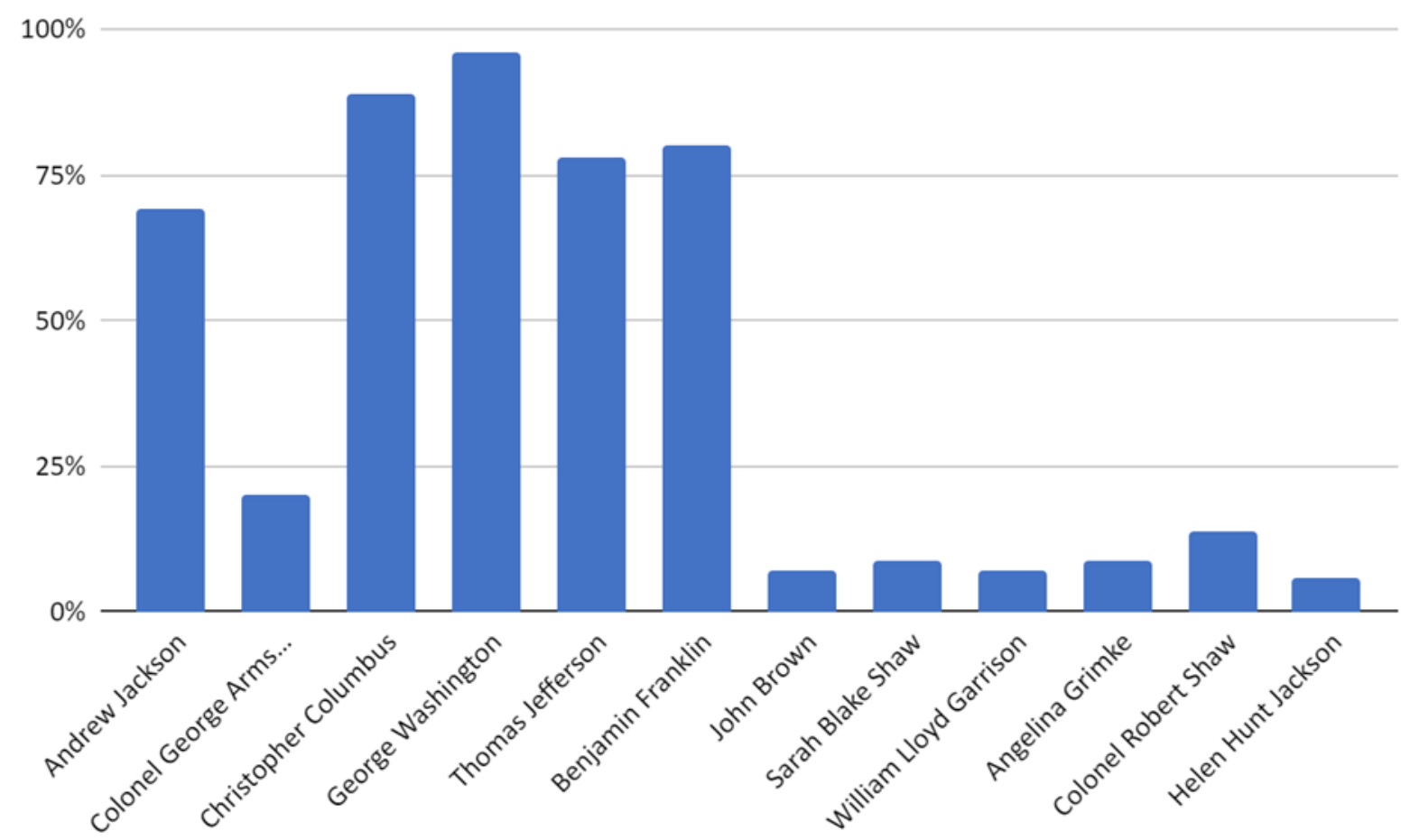

\section{Part 3: Themes from Respondents' Reflections}

Many participants attributed the disparities in their knowledge primarily to the biased, Eurocentric hidden curriculum in K-12, cultural biases, and the desire to forget the painful parts of our history (Apple, 2004; Borunda, 2012; Loewen, 2018; Zinn, 1999). Gay (2018) recommends that students question the lessons they have been taught in school. The intent of this survey question was to empower students and create a space for emancipatory thinking by asking them to reflect on the disparities in their knowledge. Thirty-one of the 122 participants explicitly stated that they were not taught about white humanists in their K-12 history courses. The following themes were the most often cited in students' responses to the survey questions:

\section{Perceived Causes of Discrepancies in Knowledge}

Curriculum. A prevailing theme in students' reflections is that curriculum is to blame for the disparities in their knowledge. More than $50 \%$ of students cited deficiencies with the history they had been taught in school, with one student writing:

I was much more familiar with the people in the first row. They are figures who have been taught to us in grade school. They would be considered to be a part of white history. Honestly, I blame the education system for not teaching myself and other(s) about the other amazing people in our history.

Other students echoed this sentiment by stating, "The bottom six were actual leaders of justice and yet we never learn of them." 
Cultural Bias and Desire to Forget. Nearly half (48\%) of the responses included cultural biases or the desire to forget the painful parts of our history as part of the cause of the disparity. Many respondents cited a culture that favors political power, men, and white people as contributing to greater knowledge of the first six individuals. Several respondents cited the fact that three of the first six individuals were U.S. Presidents, which made them more recognizable. One respondent stated, "There were more presidents presented in the first six individuals so I had some knowledge of what they were known for in history." Other respondents attributed their greater recognition of the first six individuals to history being written by those who have social power. One respondent reflected on this by elucidating on how power is viewed, saying, "history is written by the victors and better promoted by the aggressive." Part of this imbalance of power was attributed to some students' acknowledgement of how gender played a part in history. Sexism was mentioned as a factor making the first six individuals (all men) more recognizable than the second six individuals ( 3 men and 3 women), with respondents saying "I was taught more about men in history than women in history," "men are given more credit than women," and "I feel that the women did more impactful things but at the time it wasn't seen that way (because) they were women and their opinions didn't matter as much."

Racism and colonialism were also cited as reasons for the disparities in knowledge of the first six historical figures versus the second six individuals. One respondent discussed these discrepancies by adding:

There clearly was a difference between the world views of the first cluster of people and the second. There was a pretty clear pattern of most of the first group being pro-slavery while, the second group was against it. There is not enough reflection of the rest of the American population which is not only not accurate but, it is damaging to our generations now.

Students encapsulated the greater meaning behind who is represented in history curriculum and why as well as how this meaning is constructed and distorted as truth. Other participants added, "These individuals (\#1-6) were made out to be heroes, and as such, they could not have their negative values shown," and "history only focuses on the good things they did for this country but fail to mention all the horrific things they did as well." One student elaborated on the hidden curriculum of history:

The first six individuals are taught to students, their faces are memorized, and their accomplishments are heralded. But all of them were slave owners, some were known rapists. The second set of individuals were abolitionists, were white people who took risks for racial justice, and were feminists.

Other students noted the disparate world views of individuals \#1-6 versus individuals \#712. One student offered, "Yeah, the second half were all supporters of the abolishment movement, while the first six had opposite world views." Other participants added, "Antislavery men and women were not seen as significant figures when taught in school" and "we like status quo and not radicalism and activism." 


\section{Impacts of Humanist Curriculum}

Respondents Expressed Various Emotions. The workshop evoked strong emotions in many students ranging from anger and frustration to gratitude and inspiration. The most commonly expressed emotions were disgust, frustration, and incredulousness due to seeing the disparities in knowledge, which was noted by $20 \%$ of participants. One student expressed their frustration, "Honestly I'm black so it is more of the same." One student declared, "I feel rage, honestly. No wonder we have a crisis of white supremacy in the U.S." Another participant revealed, "I mainly hold just dormant anger and resentment for the former leaders of this country and how such humanists had to be either kept secretive or were erased from popular history."

Ten percent of students expressed feeling sad, bummed out, or disappointed upon learning about humanists in history. One student commented, "It just made me think about how bad American history actually is. This country is built off of horrible things and it is really sad." One student elaborated on who is represented in history and who is not by stating, "Looking at the pictures of the last six people, they sacrificed their lives for humanity and goodness. They are heroes who we don't remember nor appreciate."

Other students expressed positive feelings after learning about white abolitionists in the workshop. Nearly $15 \%$ of participants expressed appreciation and gratitude for learning about the accomplishments of humanists now and felt as though their eyes had been opened and that they had been enlightened. One student indicated their appreciation by commenting, "I think it will make me more aware of the struggles the people have endured to get the rights and privileges that we have today. I will be more thankful for everything humanists have accomplished." Another respondent indicated, "It just opened my eyes more to the unequal treatment of Euro-centric curriculum in schools." Interestingly, approximately $12 \%$ expressed feelings of interest and stated a desire to learn more. More than $7 \%$ felt amazed, inspired, hopeful, empowered, and less cynical and jaded. Participants wrote, "I think that learning this info has impacted my worldview. I feel a little less cynical and jaded about current events. It's nice to know that good people existed back then and that there were people who stood up against slavery," and "I think they are such great influencers. They inspire people like me." 
Table 3: Expressed Feelings Following Experience with this Curriculum

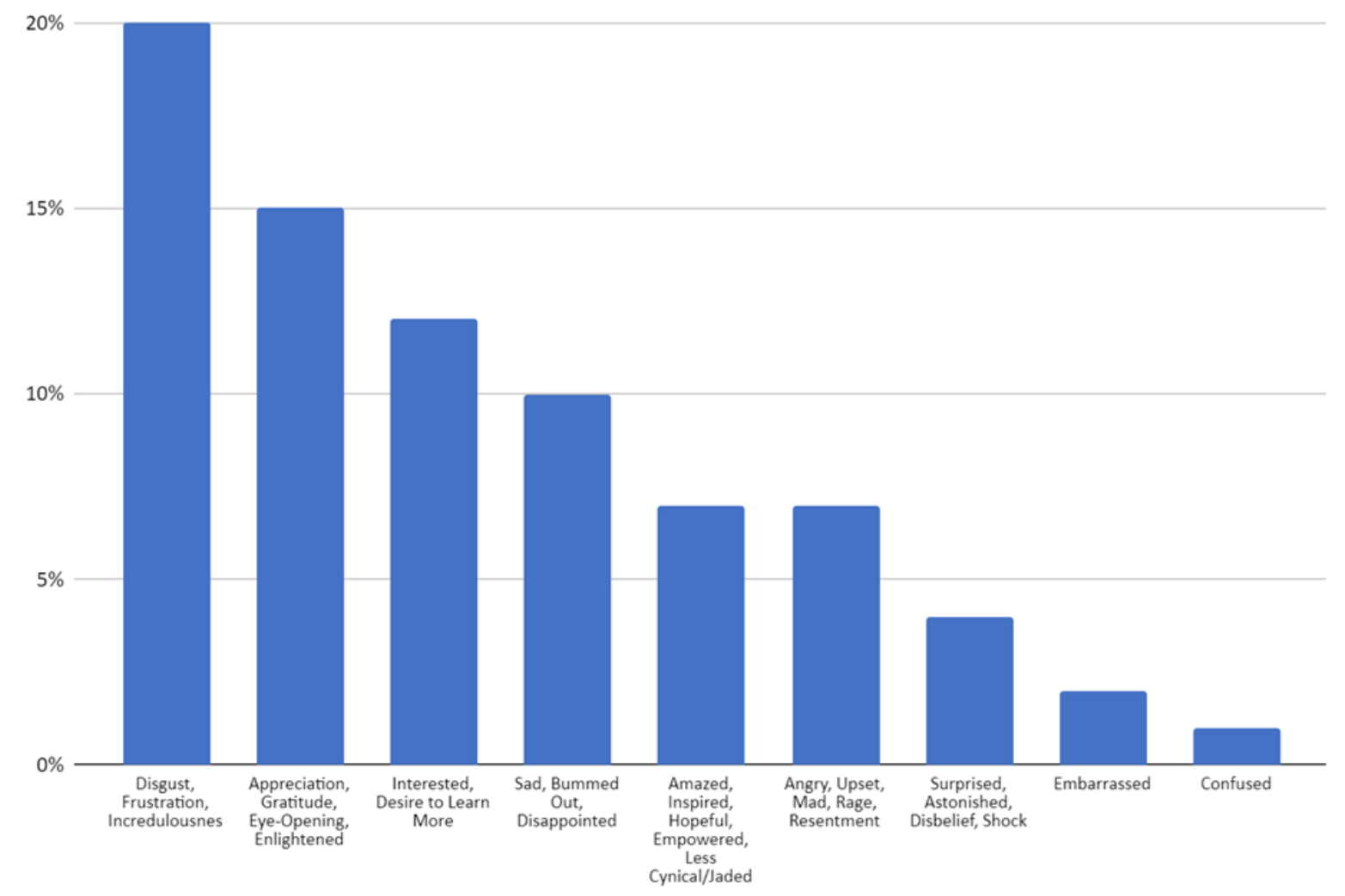

Impact on Students' Future Lives and Careers. One of the limitations of this study was the restricted time of 1-hour devoted to the topic of humanists in history. This study was intended to gauge whether an online curriculum and presentation would impact students' sense of empowerment and transformation (Gay, 2018). Would students be moved in small or large ways to act upon their newfound knowledge of humanists in history? More than $48 \%$ of participants stated the information presented in the workshop would impact their future, either by inspiring them to learn more and listen to others, motivating them to teach others and share the information they learned, and/or by influencing them to advocate for others. More than $12 \%$ stated the information presented in the workshop reinforced their existing beliefs. More than $21 \%$ of participants specifically shared feeling inspired to listen and learn more. One student wrote that the information they learned makes them want "to be more open to others and listen" and to "spend a bit more time on my History because this is what made us!" Other participants stated they were inspired to "seek out more knowledge," "dig into more of our history" and "to read more about these humanist Euro-Americans and other humanists in modern days." Other participants shared that the information presented would change how they learn, with one student stating:

I think this will change a lot in how I take in information and understand it. Now I think I have a better idea of how history is taught one sided. I think this will impact how I learn in the future and what is the whole truth. 
Another student revealed:

I think that this will push me to become more educated about the real history that I still don't fully know. My career has to work with a diverse group of individuals and I can definitely apply it to the future.

More than $15 \%$ of participants stated that the information presented inspired them to share this information and teach others. One student explained how this newfound knowledge of humanist activism influenced them:

I will do my best to keep others educated in other things rather than the basic founding fathers and touch on other important details that have led to the creation of the US. I'II make sure to not paint the facade of this nation being built on great things, because it wasn't.

Others said that they would also share the information about humanists in their personal lives, as well as their professional roles. One student wrote, "I think that information like this will change how I raise children in the future. I plan to expose them to people like this who made real change that have not been talked about in schools." Another student added that they would "inform my family, friends and my own children." Furthermore, nearly $12 \%$ of participants expressed that they were inspired to advocate on behalf of others. One student said, "I want to be more like the second line and help people;" another wrote that the information presented "helps remind me to be an advocate by listening, learning and sharing my knowledge." Finally, more than $12 \%$ of participants stated that the information presented reinforced their existing beliefs and awareness. One student expanded on how their values would influence their career, "For me it reinforces my future career in politics, I want to be on the right side of history even if my input or influence isn't recognized like the last group of people who were advocates."

Table 4: Impacts of Study on Participants ${ }^{2}$

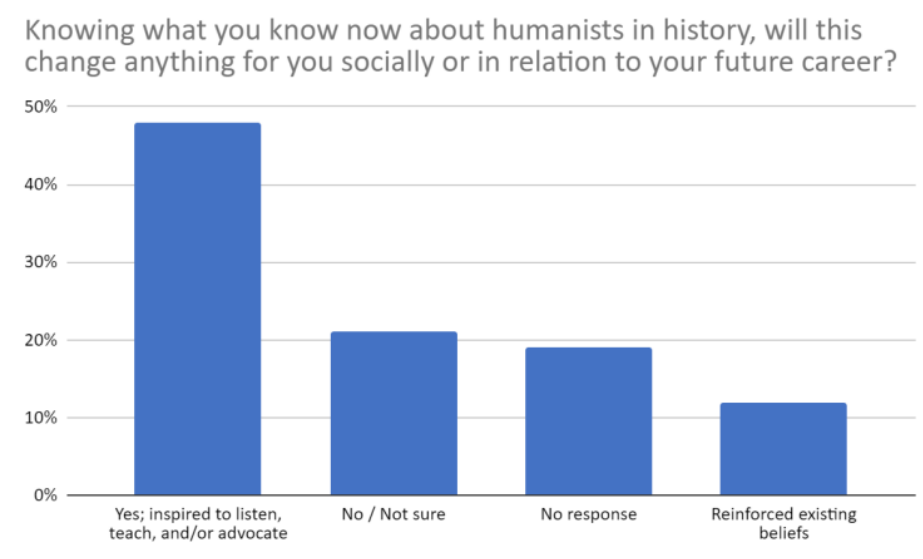

${ }^{2}$ This table explains the responses received about the impact of this study on the participants. 


\section{IMPLICATIONS}

Researchers have established that a biased curriculum perpetuates racial divisions. The lack of truth-telling perpetuates a false narrative (Apple, 2004; Borunda, 2012; Loewen, 2018; Zinn, 1999). The aforementioned authors illuminated how controversial events have been glossed over in an effort to erase our historical white supremacy. Spring (2018) expanded on the current climate of textbook adoption and censorship with a greater understanding of how these books have been increasingly politicized, particularly in the state of Texas. The importance of teachers adopting culturally responsive pedagogy in classrooms would serve to mitigate the discrepancies of historical knowledge and empower students in mutually beneficial ways in their understanding of racism (Gay, 2018). The tenets of critical race curriculum were aligned with our findings in this study (Yosso, 2002). Students identified the intersections of gender, race, and class in their understanding of humanist, used words such as master narrative and white supremacy in their interpretations of historical content, and identified brave Black abolitionists throughout the curriculum. Furthermore, students began making connections to the curriculum by questioning broader educational and societal issues such as textbook bias and the politics of who is recognized in history and who is not. These factors led many students to want to learn more about the truth in history and to advocate for others in their future careers and in their personal lives. Our findings elicit a call for increased comprehensive and difficult conversations about race starts in the classroom, whether it is through face-to-face interactions or through online learning.

Racial injustice has traditionally been scrutinized from the viewpoint of impact. Educators and policy makers generally focus on outcomes such as unequal opportunity structures, disparities in educational achievement, the school-to-prison pipeline, and disproportional health indicators, to name just a few. This nation's racialized roots can clearly be measured by the perpetual mistreatment and outcomes for BIPOC. As policy makers and educators look to the consequences of racial injustice, we often miss the ideological orientation of racism. A systemic approach that deconstructs and uproots white supremacy - at its seed disorients whiteness from its central locus of power.

The creation of whiteness and white people is a relatively young idea, and yet the travesty of this racialized ontology has unleashed a reckoning to the world (Watson, 2018; 2020). This study reveals the psychological and sociological cost of an imbalanced curriculum that promotes historical Euro-Americans whose beliefs and actions have adversely impacted BIPOC. Yet, this is not without remedy. This research also documents that even with a one-hour presentation about historical Euro-Americans who worked collaboratively with BIPOC some students became inspired. We must consider what shifts might transpire in our society if curriculum were more balanced. As previously mentioned, from this one-hour workshop, more than $48 \%$ of participants were either inspired to learn more and listen to others, were motivated to teach others and share the information they learned, and/or by influencing to advocate for others. As a path forward, this study demonstrates ways teachers can undo whiteness through 
an analysis of abolitionists in the U.S., and a strategic reframing and repositioning of people who are descendants of the European Diaspora.

An inclusive learning environment that focuses on issues of systemic racism and white privilege is inherently challenging under normal circumstances. And yet teaching towards justice must continue - even virtually. As this study reveals, positive models of historical EuroAmericans were minimally recognized by visual image (3\%) and even when provided information about these humanists, there was still an insignificant percentage of students (14\%) who had knowledge of these individuals. Yet, COVID-19 has forced our youth into expanded media usage where active youth radicalization efforts are reaching students even today (Learning for Justice, 2021). Increased inclusion of counter narratives and of positive models through our on-line curriculum and teaching are the best line of defense to these efforts to radicalize and strengthen white supremacist ideology. Accordingly, this study exposed the current quandary of the pandemic and explored the impact of an online humanist pedagogy on students 'understanding of radicalized people power.

\section{REFERENCES}

Apple, M.W. (2004). Ideology and Curriculum (3rd ed.). Routledge.

Alexander, B. (2010). The globalization of addiction. A study in poverty of the spirit. University Press.

Bernal, D. D. (2002). Critical Race Theory, Latino Critical Theory, and Critical Raced-Gendered Epistemologies: Recognizing Students of Color as Holders and Creators of Knowledge. Qualitative Inquiry, 8(1), 105-126. https://doi.org/10.1177/107780040200800107

Brown, A. L., \& Au, W. (2014). Race, memory, and master narratives: A critical essay on U.S. curriculum history. Curriculum Inquiry, 44(3), 358-389.

https://doi.org/10.1111/curi.12049

Borunda, R (2012). Healing the Soul Wounds: Racial Bridging. The International Journal of Community Diversity, 12(4): 1-12. https://doi.org/10.18848/2327-

0004/CGP/v12i04/39930

Borunda, R. (2020). What is the color of your heart? (4th ed.). Kendall Hunt Publishing.

Creswell, J. W. (2005). Qualitative inquiry and research design: Choosing among five traditions. Sage Publishing.

Creswell, J. W., \& Plano Clark, V. L. (2007). Designing and conducting mixed methods research. Sage Publications.

Delgado Bernal, D. D. (2002). Critical race theory, Latino critical theory, and critical racedgendered epistemologies: Recognizing students of color as holders and creators of knowledge. Qualitative Inquiry, 8(1), 105-126.

https://doi.org/10.1177/107780040200800107

DiAngelo, R. (2018). White fragility. Beacon Press.

Doucet, M., \& Rover, M. (2010). Generational trauma, attachment, and spiritual/religious 
interventions. Journal of Loss and Trauma 15(2), 93-105.

https://doi:10.1080/15325020903373078

DSM-V (2013). The Diagnostic and Statistical Manual of Mental Disorders.

American Psychiatric Association.

DuBois, W.E.B. (1903). The Souls of Black Folk. A.C. McClurg \& Co.

Forbes, J. (2008) Columbus and other cannibals. Seven Stories Press.

Gay, G. (2018). Culturally responsive teaching: Theory, research, and practice. Teachers College Press.

Ginsburg, M.B., \& Wlodkowski, R. J. (2009). Diversity and motivation: Culturally responsive teaching in college. Jossey-Bass.

Guthrie, K. L., \& McCracken, H. (2010). Teaching and learning social justice through online service-learning courses. International Review of Research in Open and Distance Learning, 11(3). 78-94. http://www.irrodl.org/index.php/irrodl/article/view/894/1629

Hutchison, L. F., \& White, C. S. (2020). Integrating culturally responsive and social justice pedagogy: A case study of an online doctorate of education degree program for instructional and professional leadership. Journal of Higher Education Theory and Practice, 20(2), 143-150. https://doi.org/10.33423/ihetp.v20i2.2845

Kelly, J. (2005). The great mortality. HarperCollins Publishers.

Ladson-Billings, G. (2021). I'm here for the hard re-set: Post pandemic pedagogy to preserve our culture. Equity \& Excellence, 54(1), 68-78.

https://doi.org/10.1080/10665684.2020.1863883

Learning for Justice. (2021). Combating online youth radicalization.

https://www.learningforjustice.org/professional-development/webinars/combatingonline-youth-radicalization

Leslie, A. M., \& Borunda, R. (2019). Learning from the path of our better selves. Kendall Hunt Publishing.

Leslie, A. M., \& Borunda, R. (2021). Eroding white supremacy: A curricular and humanist approach to bridging the racial reality gap, International Journal of Diversity in Education 21(1), 105-117. https://doi.org/10.18848/2327-0020/CGP/v21i01/105-117 Loewen, J. (2018). Lies my teacher told me. Touchstone.

Love, B. L. (2019). We want to do more than survive: Abolitionist teaching and the pursuit of educational freedom. Beacon Press.

McBean, T. R., \& Feinberg, J. R. (2020). Critically examining virtual history curriculum. Journal of Social Studies Research 44(1), 61-76.

https://doi-org.proxy.lib.csus.edu/10.1016/j.jssr.2019.08.002

Menakem, R. (2017). My grandmother's hands. Central Recovery Press.

Merryfield, M. (2003). Like a veil: Cross-cultural experiential learning online. Contemporary Issues in Technology and Teacher Education, 3(2), 146-171. 
https://citejournal.org/volume-3/issue-2-03/social-studies/like-a-veil-cross-culturalexperiential-learning-online/

Morong, G., \& DesBiens, D. (2016). Culturally responsive online design: Learning at intercultural intersections. Intercultural Education, 27(5), 474-492. https://doi.org/10.1080/14675986.2016.1240901

Rhodes, C. M., \& Schmidt, S. W. (2018, November 1). Culturally responsive teaching in the online classroom. eLearn, (11). https://doiorg.proxy.lib.csus.edu/10.1145/3295776.3274756

Solórzano, D. G., \& Delgado Bernal, D. (2001). Examining transformational resistance through a critical race and LatCrit theory Framework: Chicana and Chicano students in an urban context. Urban Education, 36(3), 308-342. https://doi.org/10.1177/0042085901363002

Spring, J. (2018). American education. Routledge.

van der Kolk, B. (2014). The body keeps the score. Viking.

Watson, V. (2018). Transformative schooling: towards racial equity in education. Routledge. Watson, V. (2020). What is a world without whiteness? In Medium open source. https://medium.com/@vajrawatson. June 1, 2020.

Woodley, X., Hernandez, C., Parra, J., \& Negash, B. (2017). Celebrating difference: Best practices in culturally responsive teaching online. TechTrends, 61, 470-478. https://doi.org/10.1007/s11528-017-0207-z

Woodson, C. G. (1933). The mis-education of the Negro. The Associated Publishers.

Yosso, T. J. (2002). Toward a critical race curriculum. Equity \& Excellence in Education, 35(2), 93-107. https://doi.org/10.1080/713845283

Zinn, H. (1999). A people's history of the United States. HarperCollins Publishers, Inc. 